\title{
Extravasation of antineoplastic agents in an Oncological Center
}

\author{
Extravasamento de agentes antineoplásicos em um Centro Oncológico \\ Extravasación de agentes antineoplásicos en un Centro Oncológico
}

Received: 08/24/2021 | Reviewed: 08/29/2021 | Accept: 08/31/2021 | Published: 09/04/2021

\author{
David Siqueira Gonçalves \\ ORCID: https://orcid.org/0000-0002-3714-9410 \\ A.C. Camargo Cancer Center, Brazil \\ E-mail: davidsiqueira@ hotmail.com \\ Hernandes Cerqueira de Souza Silva \\ ORCID: https://orcid.org/0000-0002-1626-7768 \\ A.C. Camargo Cancer Center, Brazil \\ E-mail: hernandes.silva@ accamargo.org.br \\ Regiane Conceição \\ ORCID: https://orcid.org/0000-0002-3144-7249 \\ A.C. Camargo Cancer Center, Brazil \\ E-mail: Regiane.conceicao@accamargo.org.br
}

\begin{abstract}
Introduction/Objective: This retrospective cross-sectional cohort study analyzed the extravasation index of antineoplastic therapy agents, demographic and clinical data. Methods: Seventy-six patients were evaluated in the period between 2017-2019. The project was approved by the Research Ethics Committee of a Brazilian Foundation. Results: In 72 months, 105,890 applications were administered, of which the incidence rate of extravasation of antineoplastic agents was $0.071 \%$. Patients $(\mathrm{N}=311)$ selected for this study had a mean age of 55.42 years and a median age of 57. The most frequent diagnoses were breast cancer (11.66\%), ovarian cancer $(10 \%)$, colon cancer (8.33), rectal cancer (8.33) and uterine cancer $(8.33 \%)$. The main variables that presented a significant impact with $\mathrm{p}$ $<0.05$ were ECOG Scale of Performance Status, ethnicity, age (risk ratio of 3\% plus for each year of life), cancer staging, lymphadenectomy, use of venous catheter, forearm puncture, use of alkylating and alkaloids agents in peripheral venous access, and patients with tumor located in the pelvis using alkylating agents. Conclusion: The findings reinforce the need for further studies, since it was not possible to compare results with some variables that demonstrated a significant increase in the risk for the event.
\end{abstract}

Keywords: Neoplasms; Antineoplastic agents; Nurses.

\section{Resumo}

Introdução/Objetivo: Este estudo de coorte transversal retrospectivo analisou o índice de extravasamento de agentes de terapia antineoplásica, dados demográficos e clínicos. Métodos: Setenta e seis pacientes foram avaliados no período entre 2017-2019. O projeto foi aprovado pelo Comite de Ética e Investigação de uma Fundação Brasileira. Resultados: Em 72 meses, foram administradas 105.890 aplicações, das quais a taxa de incidência de extravasamento de agentes antineoplásicos foi de $0,071 \%$. Os doentes $(\mathrm{N}=311)$ selecionados para este estudo tinham uma idade média de 55,42 anos e uma idade média de 57 anos. Os diagnósticos mais frequentes foram câncer de mama $(11,66 \%)$, ovários $(10 \%)$, cólon $(8,33)$, retal $(8,33)$ e do útero $(8,33 \%)$. As principais variáveis que apresentaram um impacto significativo com $\mathrm{p}<0,05$ foram a Escala ECOG de Estado de Desempenho, etnia, idade (risco de 3\% mais por cada ano de vida), estadiamento do câncer, linfadenectomia, uso de cateter venoso, punção do antebraço, uso de agentes alquilantes e alcalóides no acesso venoso periférico, e pacientes com tumor localizado na pélvis usando agentes alquilantes. Conclusão: Os resultados reforçam a necessidade de mais estudos, uma vez que não foi possível comparar os resultados com algumas variáveis que demonstraram um aumento significativo do risco para o evento.

Palavras-chave: Neoplasia; Antineoplásicos; Enfermeiras e enfermeiros.

\section{Resumen}

Objetivo: Este estudio retrospectivo de cohorte transversal analizó el índice de extravasación de los agentes terapéuticos antineoplásicos, datos demográficos y clínicos. Métodos: Setenta y seis pacientes fueron evaluados en el período comprendido entre 2017-2019. El proyecto fue aprobado por el Comité de Ética en Investigación de una Fundación brasileña. Resultados: En 72 meses se administraron 105.890 aplicaciones, de las cuales la tasa de incidencia de extravasación de agentes antineoplásicos fue del 0,071\%. Los pacientes $(\mathrm{N}=311)$ seleccionados para este estudio tenían una edad media de 55,42 años y una mediana de 57 años. Los diagnósticos más frecuentes fueron cáncer de mama $(11,66 \%)$, cáncer de ovario $(10 \%)$, cáncer de colon $(8,33)$, cáncer de recto $(8,33)$ y cáncer de útero $(8,33 \%)$. Las principales variables que presentaron un impacto significativo con $p<0,05$ fueron la Escala ECOG de 
Estado de Rendimiento, la etnia, la edad (ratio de riesgo del 3\% más por cada año de vida), el estadiaje del cáncer, la linfadenectomía, el uso de catéter venoso, la punción en el antebrazo, el uso de agentes alquilantes y alcaloides en el acceso venoso periférico y los pacientes con tumor localizado en la pelvis que utilizan agentes alquilantes. Conclusión: Los hallazgos refuerzan la necesidad de realizar más estudios, ya que no fue posible comparar los resultados con algunas variables que demostraron un aumento significativo del riesgo para el evento.

Palabras clave: Neoplasias; Antineoplásicos; Enfermeras y enfermeros.

\section{Introduction}

With the evolution of intravenous therapy, catheters became essential instruments in the treatment of cancer. The use of these devices minimized several adverse effects related to the administration of chemotherapy and supportive therapies. With this, different types of catheters are available and the choice between them is determined by several factors, such as characteristics of the prescribed chemotherapy protocol, duration of treatment, integrity of the venous network and patient preferences. Thus, nurses play an important role indicating the most appropriate device to patients in the prevention and management of complications (Custódio et al., 2019).

There are some complications with regards to intravenous infusion therapies, with infiltration and extravasation being the most common. Both complications involve inadvertent leakage of a solution into the surrounding tissue. This may be nonirritating when the agent rarely produces acute reactions or destroys tissue or irritating if the agent induces pain at the site of application or along the vein, with or without inflammatory reaction, usually without persistent tissue damage. Extravasation results in local reactions ranging from local irritation to severe tissue necrosis of the skin, surrounding vasculature, and supporting structures. These complications can also mean delays in cancer treatment, which can reduce efficacy and may require additional cycles (NHS England, 2019).

Some patients with cancer may be at increased risk for extravasation due to: 1) multiple cannulations for chemotherapy veins, which lead to vessel hardness or sclerosis; 2) lymphedemas due to previous treatment such as mastectomy; 3) patients with long-term side effects of treatment such as peripheral neuropathy; 4) injury caused by previous site extravasation; 5) multiple punctures; 6) obstructed vena cava; 7) unconscious patients; 8) confused patients, or patients with communication problems who may be unable to report pain or discomfort around the device site or decreased sensation; 9) patients suffering from comorbidities that may lead to a decrease in sensation or poor circulation of concomitant medications such as: analgesics, anticoagulants, antifibrinolytics, vasodilators, hormone therapy, steroids, diuretics, antihistamines, or intravenous antibiotics that may, depending on the drug increase blood flow, predispose patients to bleeding, suppress the inflammatory response, reduce pain sensation and others (NHS England, 2019).

It is the responsibility of nurses to analyze and monitor risk factors and intervene when neccesary, providing educational actions for the best physical and global adjustment of patients, as well as ensuring efficiency, safety, and responsible administration of these drugs. In addition to knowing the possible complications in chemotherapy treatment, nurses must have knowledge about prompt intervention in the event of extravasation. Therefore, it is essential that the institution reinforce the means that encourage the constant training, practice and guidance of these professionals, especially in relation to the management of chemotherapy treatment complications (NHS England, 2019).

The aim of this study was to analyze the extravasation index of antineoplastic agents in the period between 2017 2019 and the potential risks of extravasation, with the results evidenced in the literature. 


\section{Methodology}

This is a retrospective, cross-sectional, descriptive study with a quantitative approach. According to PEREIRA et. al 2018, this type of study enables the generation of important data to better understand the phenomenon chosen for study. The work was carried out in an outpatient chemotherapy clinic affiliated with a reference oncology center in São Paulo, Brazil.

Data collection was performed through the institution's electronic medical records system, based on notifications of events made in the Institutional Standards Portal (SE Suite 2.0 system and DocNix system). Patients who underwent treatment with antineoplastic agents during the current study period were included. Factors such as race, age, protocol used, type of medication, socioeconomic data, level of education, presence of companion during medication infusion, and death resulting from the disease after the event were also considered.

Patients who underwent some type of infiltration of a drug other than antineoplastic agents or with incomplete data that prevented the patient's identification were excluded.

For data collection we created a database in Redcap, administered by the International Research Center of the institution where the project took place. The database consists of a spreadsheet aimed at optimizing time for information search and reduction of typos. We extracted data through the MV 2000 (used in the institution until 2018) and Tasy data systems.

For each occurrence recorded in the period, we used the number of the General Hospital Registry (RGH) to search the data, and then fed the database.

\section{Results}

\section{Incidence of extravasation}

In the period from 2017 to 2019, 105,890 antineoplastic agents were administered. Of these, 311 patients were selected for the study sample, 76 of whom suffered extravasations, with 16 cases $(21 \%)$ that were not included here due to lack of registration, such as inclusion of the RGH in the notification, and thus they were excluded from the descriptive analysis, inclusion, and exclusion criteria. From this, 60 events were eligible for extraction of the data. The incidence rate of extravasation of antineoplastic therapy calculated in the period 2017 to 2019 was $0.071 \%$.

\section{Demographic Characteristics}

Participants's mean age was 55.42 (standard deviation $(\mathrm{SD})=14.54$ ) years with a median age of 57. The minimum age was 16 years and the maximum age was 88 years. Exponential of 1.030 for the risk ratio. The majority of patients were white, 208 (66.5\%), followed by brown, 41 (13.1\%), black, 13 (4.2\%), Asian, 9 (2.9\%), and other 7 (2.2\%). Thirty-three $(10.5 \%)$ records did not provide race data.

The sample consisted of a small percentage difference between genders, however the majority were female, totalling $166(53.37 \%)$, but those who presented the event were 28 , corresponding to $46.6 \%$. The total number of males was 145 $(46.6 \%)$, with those who presented the event at $32(53.3 \%)$. 


\section{Clinical Characteristics}

Table 1 - Cancer diagnosis.

\begin{tabular}{l|ll}
\hline LOCALIZATION & \multicolumn{1}{l}{ TOTAL } & EVENTS \\
\hline Head and neck & 36 & 05 \\
Abdomen and pelvis & 92 & 21 \\
Chest & 16 & 04 \\
Bones and cartilage & 08 & 001 \\
Skin & 08 & 0 \\
Breast and female reproductive system & 110 & 20 \\
Male reproductive system & 11 & 02 \\
Nervous system and skull & 03 & 01 \\
Lymphoma and myeloma & 19 & 04 \\
Other unknown location & 08 & 02 \\
Total & $\mathbf{3 1 1}$ & $\mathbf{6 0}$ \\
\hline
\end{tabular}

Source: Research data (2019).

The body surface area (CS) presented an average of 1.77913 and median of 1.76000 . The body mass index (BMI) had a mean of 26.1294 and median 25.2691.

The most frequent diagnoses were breast cancer 94 (30\%), followed by colon cancer 26 (8.3), rectal cancer 24 (7.7), larynx cancer, pharynx cancer, bronchi and lungs cancer $22(7.0 \%)$ and hematopoietic and lymphatic system $19(6.0 \%)$.

Table 2 - Performance status and staging of the sample.

\begin{tabular}{lll|lll}
\hline ECOG & TOTAL & EVENTS & STAGING & TOTAL & EVENTS \\
\hline 0 & $215(68,7 \%)$ & $26(43,3 \%)$ & I & $26(8,3 \%)$ & $10(16,7 \%)$ \\
\hline 1 & $83(26,5 \%)$ & $31(51,6 \%)$ & II & $60(19,2 \%)$ & $7(11,7 \%)$ \\
\hline $2-4$ & $9(2,8 \%)$ & $3(5 \%)$ & III & $93(29,7 \%)$ & $14(23,3 \%)$ \\
\hline & & & IV & $120(38,3 \%)$ & $29(48,3 \%)$ \\
\hline Missing & $4(1,9 \%)$ & $\mathbf{p = 0 , 0 0 0}$ & Missing & $12(4,5 \%)$ & $\mathbf{p = 0 , 0 1 3}$ \\
\hline
\end{tabular}

Source: Research data (2019).

The performance status (ECOG) of the sample was raised, according to table 2, to verify the impact that the patient's performance status has on increasing the probability of an extravasation event. Twenty-six $(44,3 \%)$ patients that presented the event fit ECOG 0 and $31(50.8 \%)$ fit ECOG 1, where the patient is fully active and able to perform at the same level as the predisease period, or as in the second case, capable of performing activities of a mild or sedentary nature, such as light office housework, where strenuous physical exertion is not needed (ACRIN, 1982).

Among the events, 52 presented mild damage and 8 presented moderate damage. Forty-three patients were treated with a cold compress and 11 used a warm compress. Of the topical solutions, 45 were treated with hydrocortisone acetate and 7 were treated with hyaluronidase. Three events required referral for outpatient follow-up; 3 for emergency department and 1 for plastic surgery. 
Research, Society and Development, v. 10, n. 11, e361101119814, 2021

(CC BY 4.0) | ISSN 2525-3409 | DOI: http://dx.doi.org/10.33448/rsd-v10i11.19814

Table 3 - Correlation of lymphadenectomy site with the event.

\begin{tabular}{|c|c|c|c|c|c|}
\hline LOCAL & & NO & YES & TOTAL & $\mathrm{p}=\mathbf{0 , 0 0 0}$ \\
\hline \multirow[t]{2}{*}{ Armpit } & TOTAL & 55 & 4 & 59 & \\
\hline & $\%$ & $83,3 \%$ & $17,4 \%$ & $66,3 \%$ & \\
\hline \multirow[t]{2}{*}{ Cervical } & TOTAL & 2 & 6 & 8 & \\
\hline & $\%$ & $3 \%$ & $26,1 \%$ & $29,4 \%$ & \\
\hline \multirow[t]{2}{*}{ Pelvis } & TOTAL & 5 & 7 & 12 & \\
\hline & $\%$ & $7,6 \%$ & $30,4 \%$ & $13,5 \%$ & \\
\hline \multirow[t]{2}{*}{ Abdomen } & TOTAL & 3 & 6 & 9 & \\
\hline & $\%$ & $4,5 \%$ & $26,1 \%$ & $10,1 \%$ & \\
\hline \multirow[t]{2}{*}{ Upper Limbs } & TOTAL & 1 & 0 & 1 & \\
\hline & $\%$ & $1,5 \%$ & $0 \%$ & $1,1 \%$ & \\
\hline Total & & 66 & 23 & 89 & \\
\hline
\end{tabular}

Source: Research data (2019).

Table 3 presents the relation of patients who underwent lymphadenectomy regardless of the site of leakage, considering the total sample and the cases that presented the event. From the data in the table it is possible to observe that there is a higher risk for those patients with cervical, pelvic, and abdominal lymphadenectomy. 
Research, Society and Development, v. 10, n. 11, e361101119814, 2021

(CC BY 4.0) | ISSN 2525-3409 | DOI: http://dx.doi.org/10.33448/rsd-v10i11.19814

Table 4 - List of drugs involved in the event.

\begin{tabular}{ll}
\hline VESICANT MEDICATIONS & TOTAL \\
\hline Doxorubicin & $2(3,3 \%)$ \\
Paclitaxel & $11(18,3 \%)$ \\
\hline IRRITANTS MEDICATIONS & TOTAL \\
\hline Bevacizumab & $1(1,6 \%)$ \\
Carboplatin & $13(21,6 \%)$ \\
Cetuximab & $1(1,6 \%)$ \\
Cyclophosphamide & $1(1,6 \%)$ \\
Cisplatin & $5(8,3 \%)$ \\
Daratumumab & $1(1,6 \%)$ \\
Docetaxel & $2(3,3 \%)$ \\
Liposomal doxorubicin & $2(3,3 \%)$ \\
Etoposide & $1(1,6 \%)$ \\
Fluoro-uracil & $7(11,6 \%)$ \\
Gemcitabine & $2(3,3 \%)$ \\
Irinotecan & $1(1,6 \%)$ \\
Nivolumab & $1(1,6 \%)$ \\
Oxaliplatin & $5(8,3 \%)$ \\
Pembrolizumab & $3(5 \%)$ \\
Not identified & \\
\hline
\end{tabular}

Source: Research data (2019).

Analysis of extravasation events showed that carboplatin was present 13 (21.6\%) times at the time of an occurrence, followed by taxol 11 (18.3\%), fluorouracil 7 (11.6\%), cisplatin 5 (8.3\%) and oxaliplatin 5 (8.3\%), as shown in Table 4 .

Of the total sample volume (311), 146 of the patients used peripheral venous access (VPA) as an infusion medium, 6 used the peripheral insertion central catheter (PICC) and 159 the central catheter port a cath as for the deployment location of the device. Below is Table 5 and 6. 
Table 5 - Device Type and Installed Location.

\begin{tabular}{|c|c|c|c|c|c|}
\hline DEVICE & TOTAL & EVENTS & & & $\mathrm{p}=0,000$ \\
\hline Peripheral & $99(42,9 \%)$ & $46(75,8 \%)$ & & & \\
\hline Port a cath & $132(57,1 \%)$ & $14(24,2 \%)$ & & & \\
\hline DEVICE & LOCAL & TOTAL & $\%$ & EVENTS & $p=0,273$ \\
\hline \multirow[t]{2}{*}{ Port a cath } & Right chest & 122 & $39,2 \%$ & $11(73,3 \%)$ & \\
\hline & Left chest & 24 & $7,7 \%$ & $4(26,7 \%)$ & \\
\hline \multirow[t]{3}{*}{ Peripheral } & Forearm & 77 & $24,7 \%$ & $32(71,7 \%)$ & $p=0,026$ \\
\hline & Hand & 57 & $18,3 \%$ & $11(24,4 \%)$ & \\
\hline & Fish & 9 & $2,9 \%$ & $2(4,4 \%)$ & \\
\hline \multirow[t]{2}{*}{ PICC } & Right arm & 6 & $1,9 \%$ & & \\
\hline & Left arm & 13 & $4,1 \%$ & & \\
\hline Missing & & 3 & $0,9 \%$ & & \\
\hline
\end{tabular}

Source: Research data (2019).

Table 6- Device Type and Gauge.

\begin{tabular}{|c|c|c|c|c|c|}
\hline DEVICE & GAUGE & TOTAL & $\%$ & EVENTS & $p=1,000$ \\
\hline \multirow[t]{3}{*}{ Port a cath } & $20 / 15$ & 137 & $94,4 \%$ & $14(100 \%)$ & \\
\hline & $20 / 20$ & 6 & $4,1 \%$ & & \\
\hline & $20 / 25$ & 2 & $1,37 \%$ & & \\
\hline \multirow[t]{2}{*}{ Peripheral } & 22 & 7 & $4,8 \%$ & $2(4,3 \%)$ & $p=1,000$ \\
\hline & 24 & 137 & $95,1 \%$ & $44(95,7 \%)$ & \\
\hline Missing & & 22 & & & \\
\hline Infusion bomb & NO EVENTS & EVENTS & & TOTAL & \\
\hline No & $138(55,9 \%)$ & $34(56,5 \%)$ & & $173(56 \%)$ & $p=1,000$ \\
\hline Yes & $109(44,1 \%)$ & $26(43,5 \%)$ & & $136(44 \%)$ & \\
\hline
\end{tabular}

Source: Research data (2019). 
Table 7 - Relationship between topography and agente.

\begin{tabular}{|c|c|c|c|c|c|}
\hline $\begin{array}{l}\text { TOPOGRA } \\
\text { FY }\end{array}$ & IMMUNOTHERAPY & ALKALOID & ANTIMETABOLITE & $\begin{array}{l}\text { CYTOTOXIC } \\
\text { ANTIBIOTIC }\end{array}$ & ACQUILANT \\
\hline Chest & $0(0,0 \%)$ & $5(31,3 \%)$ & $2(22,2 \%)$ & $2(50 \%)$ & $4(16 \%)$ \\
\hline Abdomen & $1(16,7 \%)$ & $1(6,3 \%)$ & $4(44,4 \%)$ & $1(25 \%)$ & $3(12 \%)$ \\
\hline Pelvis & $1(16,7 \%)$ & $5(31,3 \%)$ & $2(22,2 \%)$ & $0(0,0 \%)$ & $15(60 \%)$ \\
\hline $\begin{array}{l}\text { Hematologi } \\
\text { cal }\end{array}$ & $2(33,3 \%)$ & $0(0,0 \%)$ & $0(0,0 \%)$ & $1(25 \%)$ & $0(0,0 \%)$ \\
\hline $\begin{array}{l}\text { Central } \\
\text { nervous } \\
\text { system }\end{array}$ & $0(0,0 \%)$ & $1(6,3 \%)$ & $0(0,0 \%)$ & $0(0,0 \%)$ & $0(0,0 \%)$ \\
\hline $\begin{array}{l}\text { Bones/other } \\
\mathrm{s}\end{array}$ & $0(0,0 \%)$ & $0(0,0 \%)$ & $1(11,1 \%)$ & $0(0,0 \%)$ & $0(0,0 \%)$ \\
\hline Skyn & $1(16,7 \%)$ & $1(6,3 \%)$ & $0(0,0 \%)$ & $0(0,0 \%)$ & $0(0,0 \%)$ \\
\hline Head and & $1(16,7 \%)$ & $3(18,8 \%)$ & $0(0,0 \%)$ & $0(0,0 \%)$ & $3(12 \%)$ \\
\hline $\begin{array}{l}\text { neack } \\
\text { Total }\end{array}$ & 6 & 16 & 9 & 4 & 25 \\
\hline & & & & & $p=0,010$ \\
\hline
\end{tabular}

Source: Research data (2019).

The table above shows the intersection of the variables tumor site and type of antineoplastic agent used during the study period, pointing out that the alkylating agents were the ones that presented the most events in patients with cancer in the pelvis region.

\section{Discussion}

Chemotherapy extravasation has an incidence that can range from 0.1 to $6 \%$ when administered by a peripheral venous access, and 0.26 to 4.7 when in central venous access. Factors related to the chemotherapy agent itself, such as vesicant agents, drug volume, concentration, infusion time, lack of professional training and material used for catheter fixation, may influence the occurrence of extravasation (Kreidieh et al., 2016).

The clinical and demographic characteristics of cancer patients who experienced extravasation of antineoplastic agents were heterogeneous, and cases were observed in different genders, ages, tumor sites, staging, and types of treatment, demonstrating that any patient may present this type of complication. It was not possible to identify the mean volume of antineoplastic agents due to the absence of data in the notification. Patients were classified according to the severity of the event as mild $52(86.7 \%)$, moderate $8(13.3 \%)$, and severe $0(0.0 \%)$.

According to data collection, extravasation occurred more frequently in males than in females. As for age, the mean was 57 , with the maximum of 88 and minimum of 16 , exponential of 1.030 for the risk ratio, thus raising the risk for each year of life to $3 \%$. The literature differs when it comes to age and occurrence of extravasation, however, advanced age is characterized as a risk factor associated with greater venous fragility (Sagica et al., 2017).

Ferrari et al. (2016) presented data where female patients presented higher rates of extravasation compared with male patients (64\% vs. 36\%), and the mean age was 58 and 59, respectively. Other variables increased the risk for extravasation, 
such as: elderly patients; associated comorbidities (impaired circulation, vascular disease, diabetes, lymphedema, superior vena cava syndrome); coagulation abnormalities or increased vascular permeability; obesity; sensory deficit; communication difficulties (e.g., children); and prolonged infusion.

According to Schulmeister (2014) patient factors, such as advanced age and comorbidities such as diabetes are factors that increase extravasation. Contrary to a study conducted in a university hospital in Cairo by Abd El-Salaheena et al. (2018) and Sayied \& Ahmed (2017) presented an expressively higher rate for female patients between ages 18 and 30 years, justified by the profile of the patient attended, being mostly women. In the age variable when it comes to the occurrence of the event, the statistical relevance was $\mathrm{p}=0.004$, indicating that the risk to present the event increases according to the patient's increase in age.

Due to the deficiency in the data from the electronic medical records, it was not possible to measure the level of education of the selected patients. However, Abd El-Salaheena et al. (2018) reports that the low level of education may represent a higher risk for the event, particularly during cytotoxic administration. This data is congruent with other studies that demonstrate a higher risk in this population, as Sagica et al. (2017) that the origin and level of education are relevant variables from the statistical point of view with $\mathrm{p}$ value $<0.001$.

Abd El-Salaheena et al. (2018) reports that the risk for the event is higher for patients whose BMI is below 18.5, however, the mean BMI in the present study was 25.2263 , with its minimum and maximum of 16.97 and 42.16 , with $\mathrm{p}=0.140$, demonstrating that in this study, BMI was not a relevant factor that would increase risk of extravasation.

Regarding cancer diagnoses, breast cancer, colon cancer, and rectal cancer were the most prevalent, which corroborates the result presented by Abd El-Salaheena et al. (2018). The study points to the breast cancer patient having a higher risk of presenting the event. Sagica et al., (2017) highlight stomach cancer (27\%) and lung (18\%) as the most prevalent. Ferreira et al. (2016) reports 52 episodes of extravasation in patients with breast cancer; 32 in patients with gastrointestinal cancer; 10 in patients with lymphoma; 7 in patients with lung cancer and 4 in patients with prostate cancer.

The incidence of extravasation in this study was $0.071 \%$, considering the period between 2017-2019, without distinguishing the type of catheter used, while Sagica et al. (2017) mention a rate of 0.13, considering 30458 infusions in the period between 2012-2019. In a study by Jackson-Rose at al., (2017), with a sample of 739,812 infusions performed in 11 different cancer centers, they obtained a percentage of extravasation of irritating and vesive chemotherapy of $0.07 \%$ and $0.09 \%$ respectively, contrasting with a study by Abd El-Salaheena et al. (2018), which presented the value higher than the others with $11.4 \%$ incidence, being considered only infusions by peripheral venous access in a sample of 300 patients in the period of 2016.

Regarding the type of chemotherapy, this sample did not show a significant increase in risk, with $\mathrm{p}=0.283$. Carboplatin was present 13 times (21.6\%) at the time of an occurrence, followed by taxol 11 (18.3\%), fluorouracil 7 (11.6\%), cisplatin 5 (8.3\%) and oxaliplatin 5 (8.3\%). This result was also obtained by Sagica et al. (2017) who reported that the type of chemotherapy was also not a significant risk factor $\mathrm{p}=0.209$, but that taxol was $44 \%$ present in extravasation events, as well as Ferrari et al. (2016) where they presented 30 cases of taxol extravasation, 26 oxaliplatin and 16 of doxorubicin.

In the infused volume, we obtained a minimum of $4.69 \mathrm{ml} /$ hour, measured $290 \mathrm{ml} /$ hour and maximum $1,000 \mathrm{ml} /$ hour, with $\mathrm{p}=0.062$. Schulmeister (2014) reports that many cases of extravasation in peripheral venous access occur when large volumes and long-term chemotherapy are performed, such as etoposide ( $98 \%$ of peripheral events), taxanes ( $98 \%$ of peripheral events) and oxaliplatin (98\% of peripheral events).

Twenty-three patients underwent lymphadenectomy of some segment regardless of the location used for infusion of the drug $(\mathrm{p}=0.180$ ), contrasting with other studies that demonstrate a close relationship of extravasation with lymph node emptying. Abd El-Salaheena at al. (2018) reports that patients with lymphedema are less able to tolerate extravasation than 
those with normal circulation, and it was denoted in their study with a high number of patients with lymph node emptying who presented the event.

Regarding the venipuncture site, $32(69.6 \%)$ patients presented the event in the forearm region, $12(26.1 \%)$ on the back of the hand, 2 (4.3\%) in the pulse region, with statistical relevance of $p=0.013$, caliber G22 n=2 (4.3\%) and G24 n=44 (95.7\%), $\mathrm{p}=1,000)$. As for fully implanted central venous access, port a cath, $11(73.3 \%)$ in right hemithorax and $4(26.7 \%)$ in left hemithorax, with statistical relevance of $\mathrm{p}=1.000$ for the type of catheter and $\mathrm{p}=0.273$ for the side where the puncture was performed. For Sagica et al. (2017), peripheral venous access presented $p=<0.001$ for puncture of peripheral venous access in the forearm, without specific location, and is supported by Ferrari et al. (2016) who cited higher prevalence in the forearm and arm. Respectively $47 \%$ and $45 \%$ did not present cases of central venous catheter extravasation.

Regarding the use of continuous infusion pumps, 27 (43.5\%) patients used the equipment and presented with extravasation, compared to 35 (56.5\%) who presented the event and did not use the equipment, presenting a statistical relevance of $\mathrm{p}=1.000$. Abe-Doi et al. (2019) reports that even though the occurrence of extravasation was not correlated with the use of an infusion pump, it should still be avoided during the administration of chemotherapy, especially if it is classified as vesicanting or irritating, to prevent worsening of extravasation. Infusion pumps should be used with caution and guides to increase the sensitivity of the sensor to detect an increase in the pressure of the inner tube, especially at a high infusion rate. Amorim et al. (2020) correlates a higher number of incidents during long-lasting infusions such as paclitaxel (up to 3 hours) and oxaliplatin (3 hours) pump administration.

Forty-nine patients presented edema with varying intensity of the event, with $33(67.3 \%)$ light, 15 (30.6\%) moderate and $1(2.0 \%)$ mild. Seventeen patients presented hyperemia and 18 with some pain score, of which 52 (86.7\%) were classified as mild and 8 (13.3\%) moderate, there is no case classified as serious. Ferrari et al. (2016) cited a total of 94\% (107/114) of the cases presenting some symptom, while only 6\% (7/114), were asymptomatic. Among the symptomatic patients, $70 \%$ complained of edema, $20 \%$ of erythema and $10 \%$ of pain, burning or discomfort at the site of application.

Forty-three patients were treated with a cold compress, 11 used a hot compress, 45 used hydrocortisone acetate concomitance and 7, hyaluronidase topically in the affected area. All patients were followed up with until the outcome of the case, and there were no cases of sequelae or loss of function as a result of the event. Ferrari et al. (2016) found in his study that antidotes were used in 65\% of the cases, hyaluronidase in 46 of the cases, tissulfate in 16, Dimethyl sulfoxide (DMSO) in 12 and dexrazoxane in 1 doxorubicin extravasation. In about half of the cases, the administration of the antidote alone was sufficient to achieve complete recovery within 48 hours.

NHS England (2019) guides the use of hot compresses to promote vasodilation and thus stimulate blood flow in tissues, thus propagating the extravasated agent. Hyaluronidase can be used in order to promote the spread of the drug and increase the absorption of the drug. To locate and neutralize the agent, cold compresses are used to limit the spread of the outagent. It is proposed that the cellular absorption of the agent by tissues is reduced when cold compresses are used. Cold compresses can also reduce local discomfort. There are several antidotes available for certain cytotoxic agents and these are specific to the medicine and/or group, which should be considered to reduce the potential for serious tissue damage or injury.

\section{Conclusion}

The incident rate of extravasation of antineoplastic therapy calculated in the period from 2017 to 2019 was $0.071 \%$, which is below the level expected in the literature.

Through this analysis, we could verify that ethnicity, age (risk ratio of $3 \%$ increased for each year of life), ECOG, staging, lymphadenectomy (mainly in cervical, abdominal and pelvic region), PVA, use of alkylating agents in VPA, location 
of the tumor related to ECOG (especially in tumors in the thoracic and pelvic region), and patients with tumors in the pelvic region using alkylating agents were the main aggravating factors that led to the extravasation of the drug.

All events were classified as mild to moderate damage, and for 3 of these cases, it was necessary to refer to the emergency department or plastic surgery, but all evolved without permanent damage.

The findings reinforce the need for further studies, since it was not possible to compare results with some variables that demonstrated a significant increase in risk for the event. Continuous education of the team is needed regarding the importance of the adequate registration of the notification document, so that this is not a factor that compromises data analysis and consequently negatively interferes in the processes of improvements in patient care.

It is recommended that studies be conducted that better track events, with proper recording in patient records, and that compare new variables to better understand some relationship between devices, type of antineoplastic agent used, and studies that test prevention and safety strategies in administering atineoplastics to patients.

\section{References}

Abd El-Salaheena, Mona H., Ahmed, Bassamat O. \& Mahmoud, A. S. (2018). Correlates to extravasation among patient receiving chemotherapy at a university hospital. Egyptian Nursing Journal 2018, 15(1):71-78

Abe-Doi, M., Murayama, R., Yabunaka, K., Tanabe, H., Komiyama, C., \& Sanada, H. (2019). Ultrasonographic assessment of an induration caused by extravasation of a nonvesicant anticancer drug: A case report. Medicine, 98(14), e15043.

Acrin, E.-A. C. R. G. (1982). ECOG Performance Status.

Amorim, B. F., Kameo, S. Y., Silva, G. M., \& Hardman, G. L. (2020). Extravasation of trastuzumab emtansine: management in cancer patients. Journal of Nursing UFPE on Line, 14(0).

Bonassa, E. M. A., Gato, I. R. (2012). Terapêutica Oncológica para Enfermeiros e farmacêuticos. Atheneu.

Custódio, C. S., Goulart, C. B. \& Reis, P. E. D. (2019). Acessos venosos periféricos em oncologia Paula Elaine Diniz dos Reis. Diretrizes Oncológicas 2, 643651 .

Dias, S. R. S., Avelino, F. V. S. D., Moura, E. C. C., \& Costa, J. P. (2019). Padrões de cuidados em prevenção e tratamento de extravasamento de antineoplásicos baseado em evidências clínicas. Revista Enfermagem Atual In Derme, 87(25).

Faria, L. P., \& Fagundes, T. R. (2020). Extravasamento de quimioterápicos: o papel do enfermeiro na emergência oncológica. Research, Society and Development, $9(10)$

Ferrari, L. A. M., Dinoi, G. L., Saibene, G., Re, B., Balzarini, A., Giordano, L., Sala, E., \& Bregant, C. (2016). Cytotoxic extravasation: An issue disappearing or a problem without solution? Tumori, 102(3), 290-293.

Fonseca, S. M., \& Pereira, S. R. (2014). Enfermagem em Oncologia. Atheneu.

IBGE - Instituto Brasileiro de Geografia e estatística. (2019). Características gerais dos domicílios e dos moradores. https://biblioteca.ibge.gov.br/visualiz acao/livros/liv101707_informativo.pdf

Kreidieh, F. Y., Moukadem, H. A., \& El Saghir, N. S. (2016). Overview, prevention and management of chemotherapy extravasation. World Journal of Clinical Oncology, 7(1), 87-97.

Navarro, T. M. (1998). Chemotherapy Extravasation. American Journal of Nursing, 98(11), 38.

NHS England. West Midlands Expert Advisory Group for Chemotherapy. (2019). Guidelines for the Management of Extravasation of a Systemic Anti-Cancer Therapy including Cytotoxic Agents (SACT). 29p. https://www.england.nhs.uk/mids-east/wp-content/uploads/sites/7/2018/04/management-extravasation-ofa-systemic-anti-cancer-therapy-including-cytotoxic-agents.pdf

Ong, J., \& Van Gerpen, R. (2020). Recommendations for Management of Noncytotoxic Vesicant Extravasations. Journal of Infusion Nursing, 43(6), 319-343.

Pereira, A., Shitsuka, D., Parreira, F., \& Shitsuka, R. (2018). Metodologia da Pesquisa Científica. In Metodologia da Pesquisa Científica (1st ed.). https://repositorio.ufsm.br/bitstream/handle/1/15824/Lic_Computacao_Metodologia-Pesquisa-Cientifica.pdf?sequence=1. Acesso em: 28 março 2020.

Sagica, T., Conceição, C., Ferreira, J., Albuquerque, G., Costa, M., Soares, H., Ramos, A. (2020). Spill and extravasation of antineoplastic chemotherapics in a university hospital. Research, Society and Development, 9(7), 1-22, e552974320.

Sayied, N. E., \& Ahmed, Z. A. (2017). Efficacy of teaching self-management strategies on auditory hallucinations among schizophrenic patients. Egyptian Nursing Journal, 14(2), 168-178.

Schulmeister, L. (2014). Safe management of chemotherapy: Infusion-related complications. Clinical Journal of Oncology Nursing, $18(3), 283-287$. 
Research, Society and Development, v. 10, n. 11, e361101119814, 2021

(CC BY 4.0) | ISSN 2525-3409 | DOI: http://dx.doi.org/10.33448/rsd-v10i11.19814

Souza, N. R. d., Bushatsky, M., Figueiredo, E. G. d., Melo, J. T. d. S., Freire, D. d. A., \& Santos, I. C. R. V. (2017). Oncological emergency: the work of nurses in the extravasation of antineoplastic chemotherapeutic drugs. Escola Anna Nery - Revista de Enfermagem, 21(1).

Taibi, A., Ferrero, P. A., \& Derbal, S. (2020). Prise en charge de l'extravasation de chimiothérapie sur site implantable par la technique de lavage sous cutané (avec vidéo). Gynécologie Obstétrique Fertilité \& Sénologie, 48(4), 398-399. 